Romiko E Jumpamool, 2016

Volume 2 Issue 1, pp. 18-35

Year of Publication: 2016

DOI-http://dx.doi.org/10.20319/lijhls.2016.s21.1835

This paper can be cited as: Romiko, E Jumpamool, A., (2016). Measuring Head Nurses' Coaching Practice: Modifying and Testing the Instrument for Assessing Managerial Coaching Skills. LIFE: International Journal of Health and Life-Sciences, 2(1), 18-35.

This work is licensed under the Creative Commons Attribution-Non Commercial 4.0 International License. To view a copy of this license, visit http://creativecommons.org/licenses/by-nc/4.0/ or send a letter to Creative Commons, PO Box 1866, Mountain View, CA 94042, USA.

\title{
MEASURING HEAD NURSES' COACHING PRACTICE: MODIFYING AND TESTING THE INSTRUMENT FOR ASSESSING MANAGERIAL COACHING SKILLS
}

\begin{abstract}
Romiko
Lecturer of Undergraduate of Nursing Science Program STIKes Muhammadiyah Palembang, Palembang, Indonesia; Master student of Khon Kaen University, Khon Kaen, Thailand ns.romiko@gmail.com
\end{abstract}

Apinya Jumpamool

Assistant Professor, Department of Administration, Faculty of Nursing, Khon Kaen University, Khon Kaen, Thailand

pinyath@gmail.com

\begin{abstract}
Managerial coaching has been reported as a successful leadership development approach that has potential benefit for nurses. It also was recognized as a powerful tool to promote personal and professional development in the nursing profession. Therefore, there is an increasing needs for reliable and valid assessment tools to measure the coaching skills of nurses in managerial positions. This study reviewed and revised an existing instrument created by (Park, McLean, and Yang, 2007) which measured coaching skills of managers in business and industrial organization. In order to adapt the original instrument to the nursing profession, this study firstly identified the five primary dimensions of the managerial coaching skills of head nurses through both qualitative and quantitative approaches. Review experts and a pilot study were
\end{abstract}


then performed to ensure the reliability and validity, and validated the revised instrument of managerial coaching skills. The results of this study indicate the revised managerial caching skill instrument demonstrates good reliability and validity for measuring the managerial coaching skill of head nurses in a hospital setting. Hospitals can administer and use the revised instrument as an assessment tool to evaluate their nurse managers' coaching skills, and identify the areas for improvement. This allows the head nurses to more effectively manage and support the staffs' development.

\section{Keywords}

Managerial Coaching skill, Head Nurses, Validation of an Instrument, Leadership Development

\section{Introduction}

Continuously from the changing environment of health care requires health care system to deal with retrenchment and reorganization continues (Gracey, 2001). The nature of work and global competition were changing rapidly, health care organizations such as hospitals have started to produce a different leadership approach to maintain and develop their employees. In recent years, managerial coaching has been recognized by health care organizations as a new approach to leadership development that has the potential to improve the working attitude and work performance of their employees and to help clinical leaders to achieve professional and personal goals. Recently coaching in nursing have been reported as successful technique in motivating people to achieve personal and professional goals (Edelson, 2006; Hayes \& Kalmakis, 2007; Karsten et al., 2010; Kim et al., 2013; Kalkavan \& Katrinli, 2014).

In the nursing profession, the head nurse was seen as a leader, and first-line managers in a clinical setting. In their daily work, the head nurse always engaged with the staff, and have the ability to coach staff in various specific situations. They use their skills in a managerial coaching skills to support their role in contributing significantly to the field of health care and for staff developments. Coaching provides the highest form of learning, as a professional development strategies to support professional development in nursing, and has been seen as an important element in facilitating both an individual and team level to improve the performance of nursing and practice (Neale et al, 2009; Bueno, 2010; Jinks and Popovic, 2011; Narayanasamy \& Penney, 2014). It is crucial that current nurse' managers like a head nurse be able to coach the staffs effectively in order to improve their practice and performance in the workplace. 
Even though managerial coaching has started popular in nursing profession, academic research on the topic has not continued with the practice (Narayanasamy \& Penney, 2014). Many practical reports or case studies have discussed managerial coaching in nursing, but there is no work has been done empirically to measure the managerial coaching of nurse managers in hospital setting, especially for head nurses. As the consequence, the components that contribute the head nurses in performing effective coaching has not been properly refined, and there is no a valid and reliable instruments to measure effective coaching of head nurses in hospital setting.

Measures of coaching skills or behaviors have been emerging in business and industrial context such as managerial coaching behavior scale (Ellinger et al., 2003), Coaching behavior inventory scale (Noer, 2005), and managerial coaching skill assessment tool (Park et al., 2007). Three these managerial coaching instrument provided a managerial coaching framework manager's skills and behaviors in industrial and business setting.

Through a series of revisions and the validation process, (Park et al., 2007) identified five dimensions of managerial coaching skills action; each dimension has four items, twenty items in completely. Five dimensions including Open Communication, Team Approach, Value People, Accept Ambiguous, and Facilitating Employee Development. The statistically approach shown that the instrument as a valid and reliable instrument to measure managers' coaching skills in business and industrial setting.

To adapt the (Park et al., 2007)'s instrument into nursing profession, there were still need and expected areas for improvement. (Batson \& Yoder, 2012) noted that two key attributes of managerial coaching in health care organization culture, facilitating attributes are known as contributory functions to facilitate the process of coaching, but empowering attributes must be put as behaviors that support psychological empowerment and development of self-efficacy. And then, there is different context between hospital setting and industrial and business setting. The system management and roles of managers in hospital setting and industrial and business setting may be the same but the work environment and culture of them may be different.

To use managerial coaching measures to assess managerial coaching skill of nurses in managerial position, revisions in some areas of the instruments was necessary to assess the behavior of nurse managers as well as to get input and evaluation of the staff or others. This may be a more appropriate way to measure the effectiveness of coaching skills of the nurse manager 
at the hospital. Therefore, the researcher revised managerial coaching skill measures for nurses and validated the newly revised instrument.

This study was purposed to revise the original instrument and validate the revised instrument by using reliability and validity test based on the areas for improvement. This study has three research questions as below:

1.1 What are the essential dimensions of effective coaching skill of head nurses in hospital setting?

1.2 What is the evidence for the validity of the revised instruments?

1.3 What is the evidence for the reliability of the revised instruments?

\section{Literature Review}

\subsection{Definition of Coaching}

There are few different ideas regarding the definition of coaching and what constitutes effective coaching into practice. (McLean et al., 2005) viewed coaching as an approach to of organizational development in the broad picture, taking into account the daily interactions with employees and work environment. (Park et al., 2007) have also definition about managerial coaching, they saw coaching as a way to motivate, develop, and retain employees in the organization. In nursing, managerial coaching is defined as a specific dynamic relationship between the nurse managers and nursing staff proposed to increase the knowledge and skills related to the expected performance (Batson \& Yoder, 2012).

\subsection{Content Areas of Coaching Skill}

To identify the important factors as the key coaching components, the effort was made by (Park et al.,2007) with review literatures. There are two important aspects should be considered when selecting what skills are needed to practice coaching effectively: 1) the factors must be based on the review literatures linked to coaching, and 2) the factors have to reflect the interaction process of managers with their employees in the organizations. Then, a new dimension was added by (Park et al., 2007): developing employees to four dimensions copied from (McLean et al., 2005). Special skills under a dimension were added based on literature review, along with (Peterson and Little's, 2005) criticism. With this in mind, five key dimensions were (Communicate Openly, Team Work Approach, Appreciate People, Receive Ambiguous, 
Facilitate Employees' Development) noted as the key aspects to perform managerial coaching in effective way.

\subsection{A Theoretical Framework of Head Nurses' Managerial Coaching Skill}

(Park et al., 2007) have developed framework of managerial coaching, this framework consists five components. They noted these five key dimensions as the vital factor to create effective managerial coaching. The new framework revised one dimension of the framework of Parks et al. namely facilitating and empowering employee development. For effective coaching, nurse managers need to empower individuals to promote psychological empowerment and development of self-efficacy during facilitating the development of staffs.

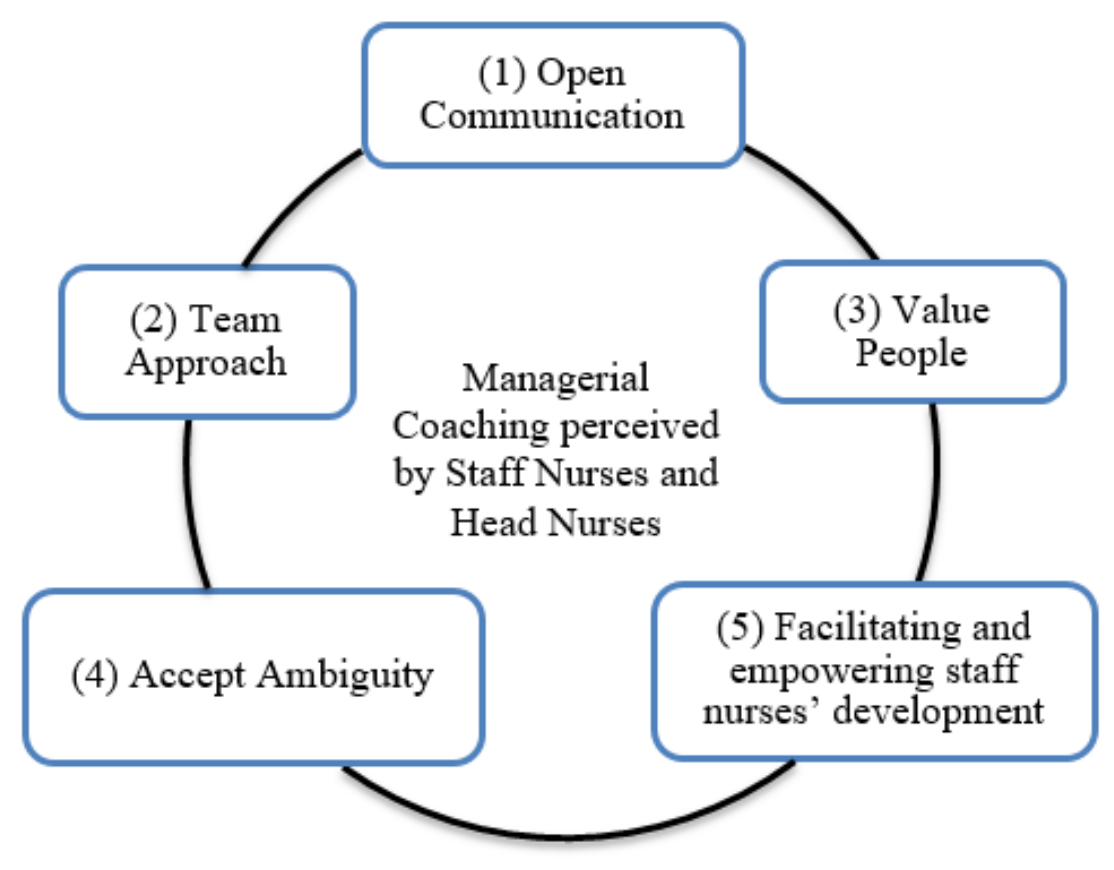

Figure 1: The Framework of Head Nurses' Managerial Coaching Skill

Effective coaching performed by the head nurse at the hospital should be based on 1) Open Communication. In approaching the job, the head nurse should take 2) Team Approach. In working with the staff, they need to be prepared various ways to 3) Facilitate \& Empower Staff Nurses' Development. They should 4) Value People are more task. In approaching the environment, they should be 5) Accept the ambiguities. The each dimension has characteristics items, for a total of forty one items. It is a circular process, these five dimensions may occur 
simultaneously. The interrelation of these five dimensions can ensure the effective managerial coaching of head nurses.

\section{Instrument Revision and Validation Methods}

Four important steps involved modifying and validating the instrument by (Benson and Clark, 1982) suggested: make a plan for the development of instruments, construct instruments, analyzing and evaluating the reliability of the instrument items with quantitative methods, and test the validity of the instrument. The modification process has four objectives, namely: (1) examine the content through a series of reviews of the literature on coaching in business and nursing; (2) revise the dimensions and items for phrasing, clarity, and behavioral observations; (3) allows for both the head nurse and nursing staff to complete the instrument; and (4) gaining quantitative evidence of reliability and validity of the instrument.

Based on the literature review, a one-dimensional in (Park et al. framework, 2007) was revised, where dimension of "facilitate employees' development" was revised to be "facilitate and empower the staff nurses' development". To cover the area of content missing in previous instruments, revision and modification of existing measurement item made by the researcher. Revision and addition items primarily from two sources: some adopted from existing studies (Park et al., 2007) and others written by the author based on literature review and in explained the concept analyzed by (Batson \& Yoder, 2012). For example, items related to the area of building relationships, communicating effectively, and facilitate and empower the learning and development of the nursing staff were strengthened through this process. The content validity of the questionnaire of head nurses' managerial coaching skills was evaluated by total five experts, including two Thai experts in the field of nursing administrations from the Faculty of Nursing, Khon Kaen University and three Indonesian experts were two nursing instructors who teach nursing administration in nursing schools and one nurse administrator in one hospital.

As a next step, a pilot study was conducted to provide evidence for the reliability of the revised instruments. The target population was nurses who are working in a private hospital in Palembang, Indonesia. This hospital was one on top private hospital in Palembang that had totally 212 nurses. For this study, only 30 nurses who working in Inpatient Department (IPD) of the hospital were considered as the participants. Among the 30 nurses, consists of four head nurses and 26 nursing staff, they were selected at random by the HR department at the hospital. 
Through the hospital's internal systems, the HR department sent letters of invitation to the nurse identified and asked them to be a voluntary participation in the study. The letter included a description of the research, contact information, and an assessment tool questionnaire. All participants filled out the questionnaire and returned the questionnaire to the researcher through HR department.

In order to test the reliability of the revised instrument, internal consistency reliability approach was employed. This approach was the best means of assessing an especially important source of measurement error in psychosocial instruments, the sampling of items. To provide evidence of the reliability of the instrument, Cronbach alpha coefficient was calculated. Reliability coefficients above .80 usually are considered is good (Polit \& Beck, 2013).

\section{Results and Discussions}

\subsection{General Characteristic of Participants}

Table 1 show the frequency and percentage of general characteristics of participants. Totally there were 30 nurses willingly involved to be participants in this study.

Table 1: Frequency and Percentage of General Characteristics of Participants $(n=30)$

\begin{tabular}{|c|c|c|c|}
\hline \multirow{2}{*}{ No } & \multicolumn{1}{|c|}{ General characteristic } & \multicolumn{2}{|c|}{ Nurses } \\
\cline { 3 - 4 } & Work setting & & \% \\
\hline 1 & Inpatient Deparment (IPD) & 30 & 100 \\
\hline 2 & Position & & 13.3 \\
\hline & Head nurses & 26 & 86.7 \\
\hline & Staff nurses & & 0.0 \\
\hline 3 & Sex & 0 & 100 \\
\hline & Male M=25.87; SD=3.72) & 30 & \\
\hline & Female & & 46.7 \\
\hline 4 & Age & 14 & 53.3 \\
\hline & $<25$ & 16 & 0.0 \\
\hline & $25-45$ & 0 & \\
\hline & $>45$ & & 0.0 \\
\hline 5 & Professional titles & 0 & 86.7 \\
\hline & Nurse Aide & 26 & 13.3 \\
\hline & Vocational Nurse & 16 & \\
\hline & Professional Nurse & 26 & 86.7 \\
\hline 6 & Education background & & \\
\hline & Diploma III & & \\
\hline
\end{tabular}




\begin{tabular}{|l|l|c|c|}
\hline & Bachelor Degree & 9 & 6.7 \\
\hline & Bachelor Degree \& Profession & 5 & 6.7 \\
\hline & Master Degree & 0 & 0.0 \\
\hline & Other: Diploma IV & 0 & 0.0 \\
\hline 7 & Work lenght & & 56.7 \\
\hline & $<5$ years & 17 & 40.0 \\
\hline & $5-10$ years & 12 & 3.3 \\
\hline & $>10$ years & 1 & \\
\hline
\end{tabular}

Totally there were 30 participants in this study. It consist of $26(86.7 \%)$ staff nurses and four $(13.3 \%)$ head nurses. As can be seen from the data in table 1, All participants (100\%) were from IPD and female, and then more than half participant ages (53.3\%) ranged from 25 to 45 with the average age of participants was 25.87 years old. Most participants (86.7\%) were vocational nurse and were graduated at Diploma III. More than half participants (56.7\%) have worked for less than five years, only one participant (3.3\%) have worked more than 10 years.

\subsection{Validity of the Managerial Coaching Skill of Head Nurses Questionnaire}

Content validity refers to the "sample adequacy for construction items which measured" (Polit \& Beck, 2006). Content validity index (CVI) approach including the item content validity index (I-CVI) and the scale content validity index (S-CVI). The researcher calculated the I-CVI for each item on the questionnaire of managerial coaching skill as a number of experts giving a rating of 3 (quite agree) or 4 (strongly agree) divided by the total number of experts. S-CVI is a percentage of the total items rated by experts as 3 or 4 (Polit \& Beck, 2006). A CVI score of 0.80 or higher is considered acceptable (Lynn, 1986; Polit \& Beck, 2006).

Based on the CVI approach recommended by Polit and Beck (2006), the researcher invited five experts to evaluate the relevance and importance of 41 items on the instrument for managerial coaching skills of head nurse, using a 4-point rating scale of CVI. As shown in Table 2, 40-item scale received ratings of 3 or 4 of the five experts, making the I-CVI rating for these 40 items was 1.0 and one item (item 8) were rated as quite or highly agree by four of the five judges would have the I- CVI of 0.80. For the calculation of the S-CVI, the number of items agreed by all of the experts combined, which in this case is 204 , and then divided by the total number of ratings: $204 / 205=0.99$. Therefore, the content validity of the Managerial Coaching of Head Nurses Questionnaire was confirmed.

The CVI evaluation of the instrument was considered acceptable by all of experts, but with some suggestions for revisions: (a) the dimension of "open communication" should promote 
head nurse and staff nurses to trust, respect, and get a good understanding of each other and serve as the basis of the development of relationship. Some items in this dimension need to be revised and changed, combine some items with similar meanings. (b) there were few items in the dimension of "facilitate and empower staff nurses' development" need to be revised and added one more item. In coaching process, a head nurse is not only facilitate the staff nurses to growth and develop, but also empower them to do it. In addition, It is necessary to add item "setting and evaluating the goals of staff nurses' learning and development" in this dimension. As the result, 41 items were retained with revision and one item was added. Totally, the questionnaire consist of 42 items under five dimensions.

Table 2: Ratings on a 41-Item Scale by Five Experts: Items Rated 3 or 4 on a 4-Point Agree Scale

\begin{tabular}{|c|c|c|c|c|c|c|c|c|}
\hline No & Item skill & $\begin{array}{c}\text { Ex. } \\
1\end{array}$ & $\begin{array}{c}\mathbf{E x} . \\
2\end{array}$ & $\begin{array}{c}\mathbf{E x} . \\
\mathbf{3}\end{array}$ & $\begin{array}{c}\text { Ex. } \\
4\end{array}$ & $\begin{array}{c}\text { Ex. } \\
5\end{array}$ & $\begin{array}{l}\text { Number } \\
\text { in } \\
\text { agreement }\end{array}$ & $\begin{array}{c}\text { Item } \\
\text { CVI }\end{array}$ \\
\hline \multicolumn{9}{|c|}{ Open Communication (9 items) } \\
\hline 1 & $\begin{array}{l}\text { When staff nurses share their feelings } \\
\text { or ask the head nurse to share his/her } \\
\text { feelings, the head nurse is } \\
\text { comfortable. }\end{array}$ & $\sqrt{ }$ & $\sqrt{ }$ & $\sqrt{ }$ & $\sqrt{ }$ & $\sqrt{ }$ & 5 & 1.00 \\
\hline 2 & $\begin{array}{l}\text { In difficult work situations, the head } \\
\text { nurses is open with his/her opinion. }\end{array}$ & $\sqrt{ }$ & $\sqrt{ }$ & $\sqrt{ }$ & $\sqrt{ }$ & $\sqrt{ }$ & 5 & 1.00 \\
\hline 3 & $\begin{array}{l}\text { In conversations with the staff nurses, } \\
\text { the head nurse shares his/her views } \\
\text { and personal values openly. }\end{array}$ & $\sqrt{ }$ & $\sqrt{ }$ & $\sqrt{ }$ & $\sqrt{ }$ & $\sqrt{ }$ & 5 & 1.00 \\
\hline 4 & $\begin{array}{l}\text { In communicating with the staff } \\
\text { nurses, head nurses view their staff as } \\
\text { an individual with values, knowledge } \\
\text { and skills and the innate ability to } \\
\text { grow and learn. }\end{array}$ & $\sqrt{ }$ & $\sqrt{ }$ & $\sqrt{ }$ & $\sqrt{ }$ & $\sqrt{ }$ & 5 & 1.00 \\
\hline 5 & $\begin{array}{l}\text { When a situation needs the head } \\
\text { nurses' experiences, the head nurse } \\
\text { willingly discusses it with the staff } \\
\text { nurses, including the mistakes. }\end{array}$ & $\sqrt{ }$ & $\sqrt{ }$ & $\sqrt{ }$ & $\sqrt{ }$ & $\sqrt{ }$ & 5 & 1.00 \\
\hline 6 & $\begin{array}{l}\text { In facing new problems, the head } \\
\text { nurse prefers to listen to staff nurses } \\
\text { opinion first rather then immediately } \\
\text { give his/her opinion }\end{array}$ & $\sqrt{ }$ & $\sqrt{ }$ & $\sqrt{ }$ & $\sqrt{ }$ & $\sqrt{ }$ & 5 & 1.00 \\
\hline 7 & $\begin{array}{l}\text { In conversations with staff nurses, the } \\
\text { head nurse tends to ask questions to } \\
\text { verify what the staff nurses say. }\end{array}$ & $\sqrt{ }$ & $\sqrt{ }$ & $\sqrt{ }$ & $\sqrt{ }$ & $\sqrt{ }$ & 5 & 1.00 \\
\hline
\end{tabular}




\begin{tabular}{|c|c|c|c|c|c|c|c|c|}
\hline 8 & $\begin{array}{l}\text { When the staff nurses talk to the head } \\
\text { nurse, the head nurse seldom } \\
\text { interrupts, ensuring that the staff } \\
\text { nurses get a full chance to share their } \\
\text { views. }\end{array}$ & $\sqrt{ }$ & $\mathrm{X}$ & $\sqrt{ }$ & $\sqrt{ }$ & $\sqrt{ }$ & 4 & 0.80 \\
\hline 9 & $\begin{array}{l}\text { When the staff nurses work with the } \\
\text { head nurse, the head nurse discusses } \\
\text { his/her expectations with the staff } \\
\text { nurses. }\end{array}$ & $\sqrt{ }$ & $\sqrt{ }$ & $\sqrt{ }$ & $\sqrt{ }$ & $\sqrt{ }$ & 5 & 1.00 \\
\hline \multicolumn{9}{|c|}{ Team approach (8 items) } \\
\hline 10 & $\begin{array}{l}\text { When there is a project related to } \\
\text { work, the head nurse usually assigns } \\
\text { it as a team tasks. }\end{array}$ & $\sqrt{ }$ & $\sqrt{ }$ & $\sqrt{ }$ & $\sqrt{ }$ & $\sqrt{ }$ & 5 & 1.00 \\
\hline 11 & $\begin{array}{l}\text { The head nurse prefers to work with } \\
\text { the staff nurses to complete tasks. }\end{array}$ & $\sqrt{ }$ & $\sqrt{ }$ & $\sqrt{ }$ & $\sqrt{ }$ & $\sqrt{ }$ & 5 & 1.00 \\
\hline 12 & $\begin{array}{l}\text { As part of a workplace group, the } \\
\text { head nurse prefers to work for group } \\
\text { consensus. }\end{array}$ & $\sqrt{ }$ & $\sqrt{ }$ & $\sqrt{ }$ & $\sqrt{ }$ & $\sqrt{ }$ & 5 & 1.00 \\
\hline 13 & $\begin{array}{l}\text { When a decision is to be made, the } \\
\text { head nurse prefers to participate with } \\
\text { the staff nurses to determine the } \\
\text { outcome. }\end{array}$ & $\sqrt{ }$ & $\sqrt{ }$ & $\sqrt{ }$ & $\sqrt{ }$ & $\sqrt{ }$ & 5 & 1.00 \\
\hline 14 & $\begin{array}{l}\text { To achieve performance goals, the } \\
\text { head nurse prefers to seeks input from } \\
\text { the staff nurses. }\end{array}$ & $\sqrt{ }$ & $\sqrt{ }$ & $\sqrt{ }$ & $\sqrt{ }$ & $\sqrt{ }$ & 5 & 1.00 \\
\hline 15 & $\begin{array}{l}\text { When analyzing a problem, the head } \\
\text { nurse tend to rely on group ideas. }\end{array}$ & $\sqrt{ }$ & $\sqrt{ }$ & $\sqrt{ }$ & $\sqrt{ }$ & $\sqrt{ }$ & 5 & 1.00 \\
\hline 16 & $\begin{array}{l}\text { In a team setting, the head nurse } \\
\text { encourages all team members to be } \\
\text { recognized each other. }\end{array}$ & $\sqrt{ }$ & $\sqrt{ }$ & $\sqrt{ }$ & $\sqrt{ }$ & $\sqrt{ }$ & 5 & 1.00 \\
\hline 17 & $\begin{array}{l}\text { The head nurse generally emphasizes } \\
\text { to creating a good partnership among } \\
\text { all team members. }\end{array}$ & $\sqrt{ }$ & $\sqrt{ }$ & $\sqrt{ }$ & $\sqrt{ }$ & $\sqrt{ }$ & 5 & 1.00 \\
\hline \multicolumn{9}{|c|}{ Value people (6 items) } \\
\hline 18 & $\begin{array}{l}\text { In decision making, the head nurse } \\
\text { emphasize on individual concerns and } \\
\text { the acknowledgements of the } \\
\text { individuals. }\end{array}$ & $\sqrt{ }$ & $\sqrt{ }$ & $\sqrt{ }$ & $\sqrt{ }$ & $\sqrt{ }$ & 5 & 1.00 \\
\hline 19 & $\begin{array}{l}\text { In discussions with the staff nurses, } \\
\text { the head nurse focuses on the needs } \\
\text { of the individuals rather than tasks at } \\
\text { hand. }\end{array}$ & $\sqrt{ }$ & $\sqrt{ }$ & $\sqrt{ }$ & $\sqrt{ }$ & $\sqrt{ }$ & 5 & 1.00 \\
\hline 20 & $\begin{array}{l}\text { When facilitating meetings, the head } \\
\text { nurse not only focuses on completing } \\
\text { the agenda but also leaves time for } \\
\text { relationship building. }\end{array}$ & $\sqrt{ }$ & $\sqrt{ }$ & $\sqrt{ }$ & $\sqrt{ }$ & $\sqrt{ }$ & 5 & 1.00 \\
\hline
\end{tabular}




\begin{tabular}{|c|c|c|c|c|c|c|c|c|}
\hline 21 & $\begin{array}{l}\text { In facing conflict between individual } \\
\text { needs and tasks, the head nurse put } \\
\text { priority on the staff nurses' needs } \\
\text { rather than getting the work done. }\end{array}$ & $\sqrt{ }$ & $\sqrt{ }$ & $\sqrt{ }$ & $\sqrt{ }$ & $\sqrt{ }$ & 5 & 1.00 \\
\hline 22 & $\begin{array}{l}\text { When managing team projects, the } \\
\text { head nurse tends to emphasize on the } \\
\text { staff nurses' needs rather than focus } \\
\text { on tasks. }\end{array}$ & $\sqrt{ }$ & $\sqrt{ }$ & $\sqrt{ }$ & $\sqrt{ }$ & $\sqrt{ }$ & 5 & 1.00 \\
\hline 23 & $\begin{array}{l}\text { In daily work, the head nurse not only } \\
\text { focuses on nursing care outcomes but } \\
\text { also considers staff nurses' needs } \\
\text { outside the workplace. }\end{array}$ & $\sqrt{ }$ & $\sqrt{ }$ & $\sqrt{ }$ & $\sqrt{ }$ & $\sqrt{ }$ & 5 & 1.00 \\
\hline \multicolumn{9}{|c|}{ Accept ambiguity (7 items) } \\
\hline 24 & $\begin{array}{l}\text { In the workplace, the head nurse } \\
\text { views differences of opinion as } \\
\text { constructive. }\end{array}$ & $\sqrt{ }$ & $\sqrt{ }$ & $\sqrt{ }$ & $\sqrt{ }$ & $\sqrt{ }$ & 5 & 1.00 \\
\hline 25 & $\begin{array}{l}\text { When the staff nurses making career } \\
\text { decisions, the head nurse stresses } \\
\text { risk-taking. }\end{array}$ & $\sqrt{ }$ & $\sqrt{ }$ & $\sqrt{ }$ & $\sqrt{ }$ & $\sqrt{ }$ & 5 & 1.00 \\
\hline 26 & $\begin{array}{l}\text { When the head nurse seeks solutions } \\
\text { to problems, the head nurse prefers to } \\
\text { try new solutions rather than use } \\
\text { proven systems. }\end{array}$ & $\sqrt{ }$ & $\sqrt{ }$ & $\sqrt{ }$ & $\sqrt{ }$ & $\sqrt{ }$ & 5 & 1.00 \\
\hline 27 & $\begin{array}{l}\text { The head nurse views disagreement in } \\
\text { the workplace as an exhilarating. }\end{array}$ & $\sqrt{ }$ & $\sqrt{ }$ & $\sqrt{ }$ & $\sqrt{ }$ & $\sqrt{ }$ & 5 & 1.00 \\
\hline 28 & $\begin{array}{l}\text { When working with the staff nurses, } \\
\text { the head nurse tends to seeks many } \\
\text { feasible answers rather than use the } \\
\text { right answer. }\end{array}$ & $\sqrt{ }$ & $\sqrt{ }$ & $\sqrt{ }$ & $\sqrt{ }$ & $\sqrt{ }$ & 5 & 1.00 \\
\hline 29 & $\begin{array}{l}\text { When dealing with a work problem, } \\
\text { the head nurse wants to explore } \\
\text { several alternatives and then find the } \\
\text { best solution. }\end{array}$ & $\sqrt{ }$ & $\sqrt{ }$ & $\sqrt{ }$ & $\sqrt{ }$ & $\sqrt{ }$ & 5 & 1.00 \\
\hline 30 & $\begin{array}{l}\text { In resolving a workplace issue, the } \\
\text { head nurse tends to tolerate open- } \\
\text { ended solutions rather than prefer a } \\
\text { definite solution. }\end{array}$ & $\sqrt{ }$ & $\sqrt{ }$ & $\sqrt{ }$ & $\sqrt{ }$ & $\sqrt{ }$ & 5 & 1.00 \\
\hline \multicolumn{9}{|c|}{$\begin{array}{l}\text { Facilitate and empower the staff nurses' } \\
\text { development ( } 12 \text { items) }\end{array}$} \\
\hline 31 & $\begin{array}{l}\text { When the staff nurses discuss } \\
\text { problems with the head nurse, the } \\
\text { head nurse encourages the staff } \\
\text { nurses to explore solutions. }\end{array}$ & $\sqrt{ }$ & $\sqrt{ }$ & $\sqrt{ }$ & $\sqrt{ }$ & $\sqrt{ }$ & 5 & 1.00 \\
\hline 32 & $\begin{array}{l}\text { The head nurse encourages the staff } \\
\text { nurses to continously find and } \\
\text { develop new skills. }\end{array}$ & $\sqrt{ }$ & $\sqrt{ }$ & $\sqrt{ }$ & $\sqrt{ }$ & $\sqrt{ }$ & 5 & 1.00 \\
\hline
\end{tabular}


Table 4.2. (continued)

\begin{tabular}{|c|c|c|c|c|c|c|c|c|}
\hline 33 & $\begin{array}{l}\text { The head nurse view staff nurses' } \\
\text { learning and development as one of } \\
\text { his/her major responsibilities. }\end{array}$ & $\sqrt{ }$ & $\sqrt{ }$ & $\sqrt{ }$ & $\sqrt{ }$ & $\sqrt{ }$ & 5 & 1.00 \\
\hline 34 & $\begin{array}{l}\text { When the staff nurses want to get } \\
\text { input from the head nurse, the head } \\
\text { nurse prefers to use reflective } \\
\text { questioning rather than provides } \\
\text { directly solutions. }\end{array}$ & $\sqrt{ }$ & $\sqrt{ }$ & $\sqrt{ }$ & $\sqrt{ }$ & $\sqrt{ }$ & 5 & 1.00 \\
\hline 35 & $\begin{array}{l}\text { In order to improve the staff nurses } \\
\text { performance, the head nurse serves as } \\
\text { a role model. }\end{array}$ & $\sqrt{ }$ & $\sqrt{ }$ & $\sqrt{ }$ & $\sqrt{ }$ & $\sqrt{ }$ & 5 & 1.00 \\
\hline 36 & $\begin{array}{l}\text { The head nurse encourages the staff } \\
\text { nurses to see the big picture of the } \\
\text { organization, not only focus on their } \\
\text { jobs. }\end{array}$ & $\sqrt{ }$ & $\sqrt{ }$ & $\sqrt{ }$ & $\sqrt{ }$ & $\sqrt{ }$ & 5 & 1.00 \\
\hline 37 & $\begin{array}{l}\text { In conducting performance } \\
\text { appraisals, the head nurse encourages } \\
\text { the staff nurses to give suggestions } \\
\text { for improving the staff nurses work. }\end{array}$ & $\sqrt{ }$ & $\sqrt{ }$ & $\sqrt{ }$ & $\sqrt{ }$ & $\sqrt{ }$ & 5 & 1.00 \\
\hline 38 & $\begin{array}{l}\text { The head nurse actively provides } \\
\text { opportunities for the staff nurses to } \\
\text { take more responsibility and } \\
\text { encourages the staff nurses to perform } \\
\text { well. }\end{array}$ & $\sqrt{ }$ & $\sqrt{ }$ & $\sqrt{ }$ & $\sqrt{ }$ & $\sqrt{ }$ & 5 & 1.00 \\
\hline 39 & $\begin{array}{l}\text { The head nurse often assigns } \\
\text { challenging work for the staff nurses } \\
\text { to stretch beyond what the staff } \\
\text { nurses have been doing. }\end{array}$ & $\sqrt{ }$ & $\sqrt{ }$ & $\sqrt{ }$ & $\sqrt{ }$ & $\sqrt{ }$ & 5 & 1.00 \\
\hline 40 & $\begin{array}{l}\text { To improve work performance, head } \\
\text { nurse constantly provides feedback } \\
\text { and regularly provide work } \\
\text { performance evaluation to the staff } \\
\text { nurses. }\end{array}$ & $\sqrt{ }$ & $\sqrt{ }$ & $\sqrt{ }$ & $\sqrt{ }$ & $\sqrt{ }$ & 5 & 1.00 \\
\hline 41 & $\begin{array}{l}\text { In coaching process, the head nurses } \\
\text { constantly provide the staff nurses } \\
\text { with resources and/or training } \\
\text { programs, especially when the staff } \\
\text { nurses face challenges. }\end{array}$ & $\sqrt{ }$ & $\sqrt{ }$ & $\sqrt{ }$ & $\sqrt{ }$ & $\sqrt{ }$ & 5 & 1.00 \\
\hline & Proportion relevant/agree & 1.00 & 0.98 & 1.00 & 1.00 & 1.00 & Mean ICV & 0.99 \\
\hline
\end{tabular}

*) Additional item for the item no. 42 based on experts' suggestions: "In facilitating the staff nurses' learning and development, head nurse willingly assist the staff nurses to set and evaluate the goals of staff nurses' learning and development". 


\subsection{Reliability of the Managerial Coaching Skill of Head Nurses' Questionnaire}

Table 3 compares the alpha coefficient between the original instrument (Parks et al., 2007) and a revised instrument. The Cronbach's alpha of the revised instruments with 42 items was 0.915 and for each of the five dimensions ranged from 0.532 to 0.812 . Among these five dimensions the dimension of "Accept ambiguity" obtained the lowest Cronbach's alpha value, while the dimension of "ffacilitate and empower staff nurses' development" had the highest Cronbach alpha value. Then, after the pilot study, most nurses agreed and understand with all of item in this questionnaire. There were only few nurses in the hospital who suggested to make the question to be simple and easy understood by participants.

Table 3: Reliability Estimates for Measuring Managerial Coaching Skills

\begin{tabular}{|l|c|l|c|}
\hline \multicolumn{1}{|c|}{ Original scale } & $\begin{array}{c}\text { Park et al. (2007) } \\
\text { Coefficient } \\
\text { Alpha with 41 } \\
\text { items }\end{array}$ & \multicolumn{1}{|c|}{ Revised scale } & $\begin{array}{c}\text { Revised } \\
\text { Measurement } \\
\text { Coefficient Alpha } \\
\text { with 42 items }\end{array}$ \\
\hline Open Communication & .87 & Open Communication & .76 \\
\hline Team Approach & .89 & Team Approach & .61 \\
\hline Value People & .84 & Value People & .59 \\
\hline Accept Ambiguity & .72 & Accept Ambiguity & .53 \\
\hline Facilitate Employees' & & $\begin{array}{l}\text { Facilitate \& Empower } \\
\text { Development }\end{array}$ & \multicolumn{2}{|l|}{$\begin{array}{l}\text { Staff Nurses' } \\
\text { Development }\end{array}$} \\
\cline { 2 - 3 } Overall & .95 & Overall & .81 \\
\cline { 2 - 3 } & &
\end{tabular}

As a whole, the coaching scale in the revised instrument has high reliability estimates, but all sub-scale instrument has moderate reliability estimates. Furthermore, the coaching scale as a whole and all sub-scale in the revised instrument, alpha has declined compared with the original version. In this study, a revised version consists of 42 items and the reliability coefficient was declined, compared with the coefficients in the original instrument.

Overall, the reliability test of managerial coaching measures of head nurse with five dimensions provide statistical support for a reliable and valid measure. In a lot of literature, open communication is known as one of the important factors to coach effectively (McLean et al., 2005 \& Park et al., 2007). The openness of head nurses for information, values, and feelings of the staff nurses can foster an open exchange of culture and helps to develop interpersonal 
relationships with the staff nurses. In addition, the head nurse must be a good listener to their staff, accept and understand clearly what they listen from the staff. In team approach, head nurses need to view their staffs as their partners and cooperate with them than working alone or in a directive or a method of control. When the head nurse asked for the respecting ideas of the nursing staff and making decisions together, their staff will be empowered and be active to learn from the head nurse. Coaching requires collaboration skills to become a real partner with one another. The next dimension was the value of people, mutual trust and positive regard between the head nurse and the nursing staff will support the sustainable of effective coaching for a long time. The head nurse should see the staff as individuals with unique beliefs, values, knowledge and skills and have the ability to grow and learn. Accept ambiguous was the dimension related to the extent to which the head nurse can receive ambiguities. The head nurse should be open to new ideas and exploring several solutions when working with their staff. In the face of complex business environments and rapidly changing, exploring possible answers rather than being stuck in the answers can help the head nurse to deal with these issues, and encourage the staff to embrace the opportunities offered by uncertainty. Facilitating and empowering staff nurses' development was also revised dimension in this study, referring to the head nurses' skills and strategies in support of the nursing staff development and promote the empowerment of individuals. These dimensions have been tested, confirming its reliability and its presence as a factor in managerial coaching skills of head nurse.

\section{Conclusions}

This study revised (Parks et al.'s, 2007) instruments for measuring managerial coaching skills head nurse at the hospital and provide additional evidence of validity. A series literature review conducted to create the theoretical foundations of coaching. In this study, the researcher identified five dimensions with included the five dimensions of (Park et al.'s, 2007) framework, namely open communication, team approach, valuing people over tasks, and receive ambiguous, and developing people. The fifth dimension was revised to measure the extent to which the head nurse using techniques to facilitate and empower the learning and development of the nursing staff. An intensive discussions with experts and a pilot study performed. After the revision process and administration, both validity and reliability were conducted that confirmed the five dimensions of managerial coaching skills of head nurse. The final five dimensions consist of 
Open Communication, Team Approach, Valuing People, Receiving Ambiguity and Facilitating and Empowering Nursing Staff Development. The dimensions of the instrument was explored and tested, ensuring the reliability and validity of the revised instrument.

\section{Implications}

Managerial coaching is one of the new approach of professional development strategies in which scientific research has continued with the practice. However, there has been no study on what constitutes an effective coaching of managers in hospitals (Kalkavan \& Katrinli 2014; Narayanasamy and Penney, 2014). Based on this study, the five dimensions of managerial coaching skills, theoretically supported and statistically valid, it leading a clear understanding of what constitutes effective coaching at the hospital. Hospital can use the framework with the five dimensions as a model of competence in developing managerial coaching skills. The revised instrument of (Park et al., 2007) in this study can be used as a valid instrument for future research on managerial coaching, especially for the nursing profession. There is no any measures to assess the managerial coaching skill of nurses in managerial position. The revised instrument also can be used as a performance assessment tool. Hospitals can administer these revised instruments to evaluate their nurse managers as a coach, and identify areas for improvement.

\section{Recommendations}

Further research is needed to cover the recent study on managerial coaching of head nurse. This research approach was employed to ensure the reliability and validity of the revised instrument. Future studies can apply different approaches to validate the instrument. The population of this study were nurses in one hospital, an extension of participants will expand the generalized of the study results. More studies are needed to examine the characteristics of instrument validity. Current data indicate moderate reliability in several dimensions of coaching skills, and it might be due to the nature of the sample homogeneous. Therefore, future studies should involve various participants from other hospitals. A greater response based on the sample size used in future study will be powerful, especially for the highly extensive statistical analysis (Kline, 2005). 


\section{References}

Batson, V. D., \& Yoder, L. H. (2012). Managerial coaching: a concept analysis. Journal of Advanced Nursing, 68(7), 1658-1669. http://dx.doi.org/10.1111/j.1365-2648.2011.05840.x

Bueno, J. (2010). Coaching: one of the fasting growing industries in the world. Therapy Today 21(7): 10-15.

Edelson, M. (2006, May).The current evolution and revolution of coaching. Commonwealth Educational Seminars, Danvers, MA.

Ellinger, A. D., Ellinger, A. E., \& Keller, S. B. (2003). Supervisory coaching behavior, employee satisfaction, and warehouse employee performance: A dyadic perspective in the distribution industry. Human Resource Development Quarterly, 14(4), 435-458. http://dx.doi.org/10.1002/hrdq.1078

Gracey, K. M. (2001). Coaching: An essential leadership skill for the advanced practice nurse. Newborn and Infant Nursing Reviews, 1(3), 176-180. http://dx.doi.org/10.1053/nbin.2001.25909

Hayes, E., \& Kalmakis, K. A. (2007). From the sidelines: Coaching as a nurse practitioner strategy for improving health outcomes. Journal of the American Academy of Nurse Practitioners, 19(11), 555-562. http://dx.doi.org/10.1111/j.1745-7599.2007.00264.x

Jinks, D \& Popovic, N. (2011). Personal consultancy. Therapy Today 22(10): 17-20.

Kalkavan, S., \& Katrinli, A. (2014). The Effects of Managerial Coaching Behaviors on the Employees' Perception of Job Satisfaction, Organisational Commitment, and Job Performance: Case Study on Insurance Industry in Turkey. Procedia - Social and Behavioral Sciences, 150, 1137-1147. http://dx.doi.org/10.1016/j.sbspro.2014.09.129

Karsten, M., Baggot, D., Brown, A., \& Cahill, M. (2010). Professional coaching as an effective strategy to retaining frontline managers. Journal of Nursing Administration, 40(3), 140144. http://dx.doi.org/10.1097/NNA.0b013e3181d042c0

Kim, S., Egan, T. M., Kim, W., \& Kim, J. (2013). The impact of managerial coaching behavior on employee work-related reactions. Journal of Business and Psychology, 28(3), 315-330. http://dx.doi.org/10.1007/s10869-013-9286-9

Kline, R. B. (2005). Principles and practice of structural equation modeling. New York, NY: Guildford. 
Lynn, M.R. (1986). Determination and quantification of content validity. Nursing Research, 35, 382-385. http://dx.doi.org/10.1097/00006199-198611000-00017

McLean, G. N., Yang, B., Kuo, M.-H. C., Tolbert, A. S., \& Larkin, C. (2005). Development and initial validation of an instrument measuring managerial coaching skill. Human Resource Development Quarterly, 16(2), 157-178. http://dx.doi.org/10.1002/hrdq.1131

Narayanasamy, A., \& Penney, V. (2014). Coaching to promote professional development in nursing practice. British Journal of Nursing, 23(11), 568-573. http://dx.doi.org/10.12968/bjon.2014.23.11.568

Neale S, Spencer-Arnold L, Wilson L. (2009). Emotional Intelligence Coaching. Kogan Page, London

Noer, D. (2005). Behaviorally based coaching: A cross-cultural case study. International Journal of Coaching in Organization, 3, 14-23.

Park, S., McLean, G. N., \& Yang, B. (2007). Revision and Validation of an Instrument Measuring Managerial Coaching Skills in Organizations. Online Submission. Retrieved 29 November 2014, from http://eric.ed.gov/?id=ED501617

Peterson, D. B., \& Little, B. (2005). Invited reaction: Development and initial validation of an instrument measuring managerial coaching skill, Human Resource Development Quarterly, 16(2), 179-184. http://dx.doi.org/10.1002/hrdq.1132

Polit, D. F., \& Beck, C. T. (2006). The content validity index: are you sure you know what's being reported? Critique and recommendations. Research in Nursing and Health, 29(5), 489-497. http://dx.doi.org/10.1002/nur.20147

Polit, D. F., \& Beck, C. T. (2013). Essentials of nursing research: Appraising evidence for nursing practice. Lippincott Williams \& Wilkins. Retrieved 28 September 2015, from https://books.google.com/ 